\title{
Towards a New Philosophy of History. European Vichianism and Neapolitan
}

\section{Hegelianism (1804-48)}

In his Introduction to the 1837 edition of Hegel's Vorlesungen über die Philosophie der Geschichte, the jurist Eduard Gans drew a comparison between the philosopher's ideas and those developed roughly a century earlier by a thinker largely unknown to the German public: Giambattista Vico. Gans (1837: ix), who had attended Hegel's lectures in Heidelberg and whose work was characteristically imbued with the principles of his philosophy of history, explained that the formulation of a worldview akin to the one illustrated in the Vorlesungen had previously only been attempted by Herder, Friedrich von Schlegel and Vico. In particular, Gans applauded the latter for elaborating a conception of history as ruled by absolute laws and Reason. In Italy, Bertrando Spaventa labelled the Neapolitan philosopher the true precursor of all Germany' in his lectures on the history of European philosophy known as La Filosofia Italiana nelle Sue Relazioni colla Filosofia Europea (1862: 31) and maintained that Vico should be recognized as the first theorist of a historicist perspective informed by a new metaphysics of ideas and by a groundbreaking intuition, namely that of Spirit (see also Spaventa [1867: 21] on this topic).

Spaventa's admiration for Vico exemplified the latter's broad appeal among Neapolitan Hegelians, whose use of Vichian historicism alongside Hegel's Geschichtsphilosophie was often examined by later commentators (Gentile 1915, Croce 1922, Piovani 1968, Tessitore 1968 and 1979, Oldrini 1973, Caianiello 2011, Origo 2011). While these works explained this tendency on the basis of the perceived intellectual affinities and thematic continuities between Vico and Hegel, however, the present article will attempt to provide a more critical discussion of their encounter. It will do so in light of Neapolitan thinkers' progressive amalgamation of Hegelianism and Vichianism, as well as the broader nineteenth-century re-discovery of Vico, informing Italians' positive response to Hegel and encouraging the merging of local thought with wider European debates. This will ultimately enable this article to invite a reflection on the inherently transnational nature of Neapolitan Hegelianism and invoke the need not to view this current as a stemming from the passive absorption of Hegel's ideas, but as the synthesis of a local and a European dimension of philosophy. 
Hegel's European receptions often went hand-in-hand with a newfound interest in Vico and, to a significant extent, revision of the latter's ideas. This might sound somewhat counterintuitive, for various reasons: first, their philosophies of history were marked by fundamental differences in terms of their premises, focus and definitions of historical development; second, Vichian historicism's reception among eighteenth- and nineteenthcentury German philosophers was superficial (Robertson 2005: 206-10). In his correspondence, for instance, Hamann (1777: 413) confessed that he was eagerly waiting for a copy of La Scienza Nuova, hoping to discover insights into economics and history, but later admitting his disappointment in exclusively coming across notions of philology. Similarly, Herder's (1797: X, 67-69) main source of information on Vico was the latter's autobiography and not La Scienza Nuova (see also Fisch \& Bergin [1944: 46-60] on this topic). Moreover, his acquaintance with the Neapolitan philosopher was filtered through the reading of Melchiorre Cesarotti's footnotes to the German edition of Macpherson's Ossian (Herder 1789: 308). Likewise, Jacobi (1811: 121-23), whose acquaintance with Vico was questioned by Victor Cousin (1828: 221), saw the him as a precursor of Immanuel Kant's transcendental method and did not turn his attention to the philosophy of history elaborated in La Scienza Nuova, but to his emphasis on mathematical sciences and the association of 'verum' and 'factum' developed in De Antiquissima Italorum Sapientia. Simply put, while they reveal traces of Vico's ideas in the German cultural landscape of the time, these considerations do not provide significant evidence regarding the reception of the Italian philosopher's views on history, hence making any connection between La Scienza Nuova and idealist historicism all the more uncertain.

In his 1976 study Vico and Herder, lasiah Berlin attempted to re-describe this relationship from the standpoint of a general re-orientation of European culture during the early nineteenth century. In the Neapolitan philosopher's works, he argued, one could identify a series of elements that, being able to 'defy time', made his ideas appealing to emerging Romantic and idealist sensitivities (Berlin 1976: xvi). Similarly, Arnaldo Momigliano (1966: 259-60) examined Vico's distinction between 'sacred' and 'profane' history in La Scienza Nuova and maintained that, during the 1800s, all those romantics, anti-clericals and pantheists who were not concerned with such a division and accepted Vico's definition of profane history as the true history, were especially keen on regarding his historicism as a 'preHegelian' philosophy of history. 
Central to these verdicts was the idea that the emergence of Romantic and idealist sensitivities in the continent had established a new conceptual horizon bounding Europeans' experience and understanding of history. This reverberated in a new approach that, while rejecting the assumption that history ought to be examined post-factually and retrospectively, namely from the vantage point of philosophical contemplation of the past, emphasised the equation of historical study with the illustration of a spiritual process of selfcreation of the people, as observable in their traditions, customs and cultural production. Thanks to its emphasis on the "histories of all nations" primacy over the 'ideal eternal history, reflecting, broadly speaking, the relationship between 'verum' and 'factum' discussed in De Antiquissima, Vichian historicism easily lent itself to this new outlook (Vico 1710: 37; 1744: I, 21).

In France, for example, Jules Michelet (1994: I, 703) aimed at slotting La Scienza Nuova into his very own 'treatise on the philosophy of history', as he told his mentor Victor Cousin in 1824. In order to do so, he found himself obliged to follow Vico in reasoning from a very specific intuition: that 'humanity is its own creation' (Michelet 1839: 341; see also Mali [2003: 85] on this point). Moreover, as argued by Joseph Mali in The Legacy of Vico in Modern Cultural History (2012: 64), Michelet re-worked, both in his Histoire de France (1837: I, 193206, 353-56; V, 44-79, 87-88) and Histoire Romaine (1839: 334-44), Vico's theory of myth to show how foundational events, such as the martyrdom of Saint Denis, the conversion of Clovis, the Christian monarchy of Saint Louis and the life of Joan of Arc, had contributed to creating a collective imagination crystalised in an idealised picture of the French nation, the 'mère patrie' (see also Crossley [1993: 183-250] on this topic).

Michelet's reading of Vico was spurious and tainted with idealist tendencies. This can be observed by examining his 1827 translation of La Scienza Nuova, which remained, for several years, the most influential book written on the Neapolitan philosopher. This was the case both in France (Michelet 1869: 215; 1994: I, 702) and, to a great extent, Italy, where it influenced Giandomenico Romagnosi and Carlo Cattaneo's interpretations (Romagnosi 1832a: 252; Lacaita, Gobbo \& Turiel 2003: 334-35). The Frenchman's translation was a largely edited one: the title of the book, for instance, was not La Science Nouvelle, but Principes de la Philosophie de I'Histoire de Vico. Hoping to render Vico's theory more accessible to contemporary readers, Michelet altered sections of it, making them more consistent with his own pre-existing philosophical orientation. For example, Vico's own interpretation of history 
as cyclical, was removed and replaced by a Hegelian idea that this was an objective and collective process, featuring a linear progression anchored to a solid dialectics (Michelet 1827: I, 70-84). ' Other sections, especially those dealing with philological enquiries on the origin of modern languages, were heavily downsized and often relegated to footnotes. Michelet's goal in writing the Principes was therefore the elaboration of an account of the philosophical mechanisms directing historical development that was deprived of its Vichian empirical and methodological underpinnings. In consequence, his book was simply not consistent with the Neapolitan philosopher's broader intention to articulate a 'new science' able to amalgamate historical analysis with anthropological, philological and linguistic observations, deemed by the Frenchman too obscure for his contemporaries (Mali 2012: 33-34).

Michelet's selective reading of Vico reflected intellectual concerns and a philosophical inclination that had more in common with Hegel's philosophy of history, with which he had become acquainted in 1824, when he followed Cousin's Parisian lectures on the German philosopher. In describing the historical development of modern nations as the outcome of the perpetual honing of a mythical image, for example, the French thinker explained the Hegelian process known as 'Aufhebung', the notion of 'sublation' stemming out of selfnegotiation in history (Hegel 1816: 88-113; 1817: 172-76; see Kaufmann [1965: 144] on these concepts), according to distinctly Vichian categories.

Not surprisingly, the juxtaposition of a Vichian notion of nation and a teleological, Hegelian account of historical development also featured extensively in Michelet's most famous work, Histoire de la France. Here, the tension between local and private interests and the voluntary bonds required for the well-being of society was resolved thanks to the idea of 'a great homeland, by which [man] imagines himself in the destinies of the world. This homeland, an abstract idea that owes very little to the senses, will lead him to a renewed effort to realise the idea of a universal fatherland, of the city of Providence' (Michelet 1837: 129). It was not the Hegelian Spirit at work here, via the 'Cunning of Reason', but the mythical image of the French nation.

While the romantic and idealist re-orientation of European culture had led Michelet to read Vico in ways that projected a characteristically Hegelian agenda onto La Scienza Nuova, Italian authors too viewed the eighteenth-century Neapolitan philosopher through a similar conceptual lens, regarding universal history to be accessible via the examination of nations' history and their cultural production. Alessandro Manzoni (1822: 63), for instance, 
disconnected Vichian historicism from its anthropological and linguistic underpinnings, viewing it as concerned with 'a universal motion of history' on the basis of 'general principles informing nations' nature'. Writing from his Milanese exile after the fall of the Neapolitan Republic in 1799, Francesco Saverio Salfi published, a volume entitled Dell'Uso dell'Istoria, in which he maintained (1807: 7-14) that a 'general law of progress' could indeed be inferred on the basis of nations' historical development. In Florence, Gabriele Pepe, who had defended the Neapolitan Republic at the end of the eighteenth century, frequently collaborated with the local periodical Antologia. In his articles, Vico was often understood as the most original maker of a novel and sublime historical critique' that, by providing guidelines to regulate historical inquiry, had disclosed 'an eternal history, able to explain that of both past and future peoples' (Pepe 1824: 2). Simply put, Manzoni, Salfi and Pepe's testimonies, while failing to acknowledge the Neapolitan philosopher's intention of crafting a whole 'new science', almost certainly due to a superficial knowledge of La Scienza Nuova, applauded him for articulating an idea of 'universal history' that had little to do with history's most tangible and concrete dynamics, which Vico himself $(1744: 1,21)$ had labelled, in La Scienza Nuova, 'storie di tutte le Nazioni'.

This was no mere conjecture on part of these Southern exiles: even if they did not stem from a direct engagement with the growing idealist mentalities, their contributions nonetheless signalled important conceptual shifts in Italians' historical imaginations. Consistent with Isaiah Berlin's analysis, Martin Thom's study Republics, Nations and Tribes (1995: 192-94) examined how early romantic historiography placed itself in opposition to the worldviews of the 1700s in attempting to decode nations' spiritual development on the basis of a broader notion of historical progress. The problematisation of the relationship between Vico's 'ideal eternal history' and the realisation 'in time' of the 'histories of all nations', visible both in Michelet and among Italian thinkers, was therefore a direct implication of these conceptual changes. This intuition was particularly prominent in the writings of one among Naples' most illustrious émigrés, Vincenzo Cuoco, who had settled in Milan in 1800 after the 1799 Revolution, and contributed, perhaps more than any of his contemporaries, to Vico's early nineteenth-century re-discovery.

In the essay Giambattista Vico e lo Studio delle Lingue come Documento Storico, Cuoco (1804: 80) slotted Vico, 'a man preceding his contemporaries by a century', into a fundamentally European dimension of philosophy, highlighting his elaboration of a new 
epistemological approach capable of disclosing 'man's ideas' via the analysis of 'the words of a people'. Cuoco reckoned that Vico's historicism, despite remaining largely ignored upon its initial appearance, had nonetheless 'ended up flourishing in Germany more than in Italy'. His 1806 work La Filosofia di Giambattista Vico further reasoned around the connection between La Scienza Nuova and the emerging German idealist philosophy: when arguing that the principles and the methods of [Vico's] philosophy are platonic, [which means that] that which is true is always ideal, and analogous to the nature of our own mind, which he believes to be unchangeable', Cuoco (1806: 306) maintained that 'his notion of truth refers exclusively to that which is ideal. Those things theorised by the German school in the last few years, have already been thought of - and executed by - Vico roughly one century earlier'.

This verdict stemmed from a specific reading of La Scienza Nuova, drawing its author closer to German idealist sensitivities. Central to this operation was the distinction between two types of history: a philosophical and universal one, the 'ideal, eternal history', on the one hand, and the concrete circumstances reflecting the trajectory of the former, termed 'histories of all nations', on the other. While present in the pages of La Scienza Nuova, this dichotomy acquired greater poignancy in Cuoco's analysis. The chief implication of the Neapolitan exile's problematisation of this tension was the need to re-think the relationship between the unity of universal history and the multiplicity of the forms in which this was realized: Cuoco, writing under the spell of early nineteenth-century cultural sensitivities, found himself unwilling to accept the subordination of the 'ideal eternal history' to the 'histories of all nations', as advocated by Vico (1744: I, 31-32, 117, 144). He took issue with the Neapolitan philosopher's intuition that the mythical foundations of a nation could be reconstructed via the study of their cultural production in history: unity, Cuoco believed, should not exclusively be sought in the foundation of nations, but in their historical existence as a whole. The Vichian focus on facts, particulars and individual circumstances therefore required a unifying principle of universality.

Cuoco (1806: 317) wrote: 'There exists, according to Vico, an eternal ideal of truth independent from the opinions of men. This truth is in the hands of Providence, and it comprises the entire range of possibilities'. This fundamental truth was said not to belong to the sphere of individual circumstances or the specific life of a given people, but to the broader realm of ideas alone. The chief principle of Vico's philosophy, Cuoco (ibid.: 306) asserted, was 
that 'that which is true is always ideal', or, conversely, that ideas are the only true reality: these ideas were seen as the driving forces behind human actions.

Therefore, with human circumstances fully subject to a universal unifying truth, it was necessary for them, 'despite their extraordinary variety', to accept 'the guidance of Providence, the true conductor of the Universe', ensuring that all human actions remained 'within the limits of the absolute truth, that eternal universal truth, that is positioned in the mind of Providence' (ibid.). Thus, by completely turning on its head Vico's statement (1744: I, 144) that 'the order of ideas must proceed according the order of things', Cuoco transformed the ideal of history presented in La Scienza Nuova into a process directed by a universal force. Consequently, by investigating the 'only absolute and universal truth, which exists before things come into existence', Cuoco (1806: 317) believed it possible to understand things at an individual, empirically observable level.

The consequences of Cuoco's identification of a tension between universal and particular history, as well as his undeniable preference for the former, were significant. Just like Michelet, he operated a selective reading of Vico that, while drawing attention to his philosophy of history, prompted a noticeable distortion of the ideas featured in La Scienza Nuova. Establishing the dichotomy between 'ideal eternal history' and the conditions in which this would concretely come to be embodied, Cuoco ultimately depicted Vico as the proponent of a universal conception of history, to which individual circumstances, contexts and events, namely the true focus of La Scienza Nuova were entirely subordinated. This was not a characteristically Vichian view of history, but certainly one that pushed historical imaginations in an idealist direction.

By the 1830s, Michelet's Principes and Cuoco's essays on Vico represented the most influential contributions to Italian intellectuals' re-discovery of Vichian historicism and its reimagining consistent with romantic and idealist sensitivities (Croce 1922b: 231; De Francesco 1998; Biscardi \& De Francesco 2002; Haddock \& Sabetti 2014: xi): the former was widely read in Turin, Milan, Florence and Rome, while the latter in Lombardy and southern Italy (Romagnosi 1832a: 250). Unsurprisingly, these years witnessed the proliferation of monographs on the Neapolitan philosopher, ranging from Luigi Tonti's 1835 Saggio sopra la Scienza Nuova di Vico to Francesco Predari's 1836 edited collection of Vico's Opere, from Giuseppe Ferrari's La Mente di Giambattista Vico in 1837 and Vico et l'Italie in 1839 to the southern thinker Ottavio Colecchi's Giambattista Vico in 1843, from Cesare Marini's 
Giambattista Vico al Cospetto del Secolo XIX in 1852 to Epifanio Fagnani's Della Necessità e dell'Uso della Divinazione Testificati nella Scienza Nuova di G. B. Vico in 1857. Unsurprisingly, these works presented an image of Vico consistent with Michelet and Cuoco's exegeses. Reflections on the Neapolitan philosopher acquired increasingly politicised overtones, with Giandomenico Romagnosi (1832a: 246-52) highlighting, for example, the possibility of redescribing nations' civic and political perfectibility from the standpoint of La Scienza Nuova's ideal of historical development (see also Romagnosi [1822: 19-49; 1832b: 61-76] on this topic. On Romagnosi's concept of 'civic philosophy', see Moravia [1974: 49-52]). Romagnosi's 1832 book Dell'Indole e dei Fattori dell'Incivilimento con Esempio del suo Risorgimento in Italia thus made Vico part of Risorgimento political thought and, in doing so, it highlighted the need, for contemporary debates on Italy's civic and political progress, to engage with his ideas.

Romagnosi's best-known pupil, Carlo Cattaneo, was especially receptive to his mentor's arguments and applauded him for his intuition that Vichian historicism easily lent itself to the formulation of a civic ideology. While Vico had proposed 'an ideal, eternal history common to all nations [...], by means of which the history of individual peoples' civilisation can be reconstructed', Cattaneo (1839: 50) noted how 'the study of individuals at the core of mankind' paved the way for a 'social and civic ideology'. This statement signalled a reading of La Scienza Nuova strongly reminiscent of Cuoco's emphasis on the notion of 'ideal eternal history'. Cuoco's influence was also particularly visible when Cattaneo (ibid.: 67) described both Vico and idealist philosophers as concerned with the same issue, namely the tension between 'the progressive manifestation of the Absolute in history' and the 'temporary necessity and transitory sanctity' of its deployment. This, for Cattaneo, was evidence of the presence, in La Scienza Nuova, of a mechanism of historical dialectics: a process of selfnegotiation informed by a necessary, universal principle, 'the progressive triumph of morals and Right, via the ongoing contrast of human freedom and the necessity of things'.

By identifying, in Vico's work, a dialectic of human freedom and the constraints imposed by history's material conditions, Cattaneo (ibid.) further exasperated Cuoco's problematisation of the dichotomy of 'ideal eternal history' and its concrete, epoch- and context-bound, historical circumstances. At the same time, his views went beyond even Cuoco's, as they posited a direct continuity between Vico and Hegel, deemed to have 'developed a variation' of Vichian historicism by maintaining that 'history is the progressive development of ideal justice, [...] the objectivation of the Idea' . Just as Michelet had described 
Vico's account of the tension between local interests and voluntary social bonds as a form of dialectics, resolvable in the unity of a nation's mythical image, Cattaneo understood Vico's philosophy of history as centred upon the notions of justice and morality, continuously perfected via a dialectic process.

It is interesting to note how Cattaneo' interpretation (ibid.: 45) was consistent with the revision of La Scienza Nuova operated by Michelet in his Principes, a text which the Milanese author had become acquainted with via Romagnosi and Ferrari (Cospito 2002, 45.; Rubini 2016: 13). His library, in fact, contained three editions of this book: one in French, edited by Michelet in 1835 and two in Italian, edited by Francesco Predari in 1835 and Giuseppe Ferrari in 1837, respectively (Lacaita, Gobbo \& Turiel 2003: 334-35). The similarities also extended to the two writers' rejection of Vico's conception of history as cyclical. This, labelled 'dreary returns of decadence' and absent in Michelet's Principes, was deemed to be too mechanistic, but the Milanese author also provided an explanation for this. He believed that Vico 'had studied Plato and therefore regarded man as a being in decadence, ultimately failing to grasp the idea of perpetual progress' (ACMil, f.15(4): 21-22). While praising Vico for elaborating a seminal conception of history, revolving around the progressive refinement of justice, he made it clear that only a linear notion of progress, rather than a cyclical one, could enable Providence to 'extrapolate justice from iniquitous passions, later coming to progressively realise it within the world of nations' (Cattaneo 1839: 66). So as to amend Vico's shortcomings, Italian intellectuals had therefore to turn their attention to nineteenth-century theories of progress, most notably formulated, unsurprisingly, by German idealists (ibid.: 4549).

While Cattaneo's views remained consistent with Cuoco and the Lombard intellectual context in re-imagining Vico as a proponent of a universal history, casting aside the philological and anthropological considerations appearing in La Scienza Nuova, and with Michelet's in objecting to a cyclical view of historical development, his observations posited a connection between Vichian and Hegelian historicism with unprecedented clarity. The methodological apparatus and scope of Vico's inquiry, Cattaneo believed, ought to be supported by a more convincing account of progress. This operation, in his view, was being accomplished by Romagnosi in Italy and, by the German idealists, most notably Fichte and Hegel in Germany. By the mid-1830s, then, the trajectory of Vico's re-discovery had reached a critical turning point, with his philosophy of history being perceived as methodologically 
sound, but unable to explain how societies develop, flourish and perfect themselves. As made clear by Cattaneo, this was not enough to abandon Vico's ideas altogether: after all, he was still seen as an exceptional theorist of historical time and the proponent of a universal history that resonated with nineteenth-century sensitivities, especially German idealists': what was needed was an attempt to amend Vico's shortcomings. Neapolitan Hegelians were prompt in rising to the occasion.

A blueprint for Neapolitan Hegelians' amalgamation of Vico's and Hegel's philosophies of history was initially provided by Pasquale Galluppi and Ottavio Colecchi's merging of Vichianism and Kantianism. Galluppi (1847: VI, 258) read La Scienza Nuova through the lens of what he called Kant's 'transcendental psychologism' and thus resolved Cuoco's problematisation of the tension between an 'ideal eternal history' and history's concrete, empirically observable conditions by formulating a vision of historical development understood as the concatenation of 'the thoughts and the will of everyone', leading to an uncompromising, anti-metaphysical, rejection of any kind of 'ideal eternal history', or any notion of a priori historical mechanisms. The identification of historical laws was said to hinge entirely on the rational inferences made by the thinking subjects with regard to the relationship among 'past, present and future' (ibid.: VI, 124). As a result, historical laws were equated to an 'experimental truth, not a metaphysical one', a 'synthetic, rather than analytic truth', a 'contingent, rather than necessary truth' (ibid.: V, 216).

Colecchi (1843: II, 231), instead, used Vico, the theorist of a 'civic theology of Providence, according to reason' able to mediate between 'divine' and 'human things', to overcome the perceived limitations of Kantianism. Colecchi (ibid.: III, 127) regarded Kant's method as 'absurd', because 'it situated itself beyond experience, in order to interrogate that which is offered by experience itself'. As a result, 'there is a great difference between our way of doing philosophy and Kant's, namely that Kant moves from the universal towards the particular, while we, via a completely antithetical procedure, move from the particular to the universal'. In an attempt to devise a logically tenable philosophical principle allowing to 'move from concrete judgment in order to ascend toward the universal', Colecchi identified Vico's 'new science', as the optimal instrument to address this problem. This was because it was able, via 'philological and philosophical proof' to demonstrate the immanence of Providence in the world, hence rendering this universal principle intelligible via the examination of the man-made 'civic world of nations' (ibid.: II, 235). 
The most immediate implication of the examples set by Pasquale Galluppi and Ottavio Colecchi was the dissemination of their approach to the study of German philosophy among their students, whose important contributions to the development of a Hegelian movement in Naples have generally been given little weight by later commentators (Cione 1960, Oldrini 1969 and 1973, Losurdo 1997). Just as their mentors had sought to investigate the continuities between Kant and Vico, these young thinkers traced a new intellectual history of the Mezzogiorno, emphasising the transnational encounters in which the region had continuously engaged, with Vico and Hegel emerging as the chief figureheads of this new view. The most prolific proponent of this mentality was perhaps Stefano Cusani, who, born in the town of Solopaca in 1815, met the other soon-to-be Hegelians in Basilio Puoti's private school, including Francesco De Sanctis and Stanislao Gatti, with whom he founded the periodical Museo di Letteratura e Fllosofia in 1841, leading it until his premature death in 1846.

Following Colecchi's teaching, Cusani (1838: 107-08), deemed Hegelianism able to interrogate the 'immortal part of history', namely 'the linkage among causes and effects, reasons, general facts, the ideas which they conceal under the cloak of their exteriority', but emphasised the need not to restrict philosophical speculation to the investigation of history's 'premature generalities' alone, via an unconditional reliance upon 'metaphysical formulae'. These reflections represented the entry point to the author's incitement to perfect a new philosophy of history able to accommodate both Hegel and Vico, albeit in a markedly antimetaphysical vein, akin to Galluppi and Colecchi's reading of Kantianism. Central to this process was the identification of history's dual nature: 'the material and the spiritual parts of all visible events'. While Hegel appeared to provide a convincing account of the latter, the analysis of the former was deemed by Cusani to be viable only within the coordinates of the 'new science' forged by Giambattista Vico, namely via the examination of people's languages and cultural production.

At the forefront of Cusani's philosophical speculation, therefore, lay an investigation into the intersection of history's absolute mechanisms and its concrete, tangible, conditions. This, in turn, was informed by the need to amalgamate two competing traditions of thought: one that, due to its idealist emphasis on history's absolute external principles, mistakenly rendered man's experience of history 'passive and fatal'; and another that, as exemplified by Vico, 'sought within man the principle and the law informing mankind's development', but 
failed to recognise 'exterior nature's influence' on man's historical existence (Cusani 1842: 100). In other words, Cusani's proposition of a merging of Vichian historicism and a Hegelian account of absolute history was effected by the need to mediate between two opposite understandings of man's experience of history: the one, championed by Hegel and the other German idealist thinkers, portraying it as an effect, the other, articulated by the local tradition and most visible in La Scienza Nuova, viewing it as a cause.

A similar outlook was formulated by Stanislao Gatti, (1843: 140), born in Naples in 1820, who further encouraged the amalgamation of Vico and Hegel, illustrating the continuities between their philosophies of history: as explained in a lesson by him dating back to 1843 , modern historicism, born 'in Vico's great mind', had come to take different forms in other regions of Europe. In particular, the tripartite division of history imagined by the eighteenth-century Neapolitan author was said to have been re-thought by German philosophers (ibid.: 157-64). Schelling, for instance, described it as the dialectical interplay of 'the age of the infinite' and 'that of the finite', resolving itself in 'a third one, namely that of the one's relationship to the other'. Fichte too forged his philosophy of history on the basis of the progress from three distinct epochs: 'the first one is that of the not-I, the second one that of the $I$, the third one that of the fusion of the not- $I$ and of the $l^{\prime}$. Finally, Hegel managed to fully abstract this tripartite division, translating it into a dialectic of unmediated ideas. His account of history, postulating the resolution of 'unity' and 'variety' into 'unity in variety', was said to be an abstract reflection of a Vichian interplay among 'the people, individuality, the individuality of a people'. In summary, Gatti's composite Vichian Hegelianism revolved around the possibility of contemplating the progressive development of Spirit via the analysis of its 'clearest manifestations', such as language, in an attempt to replace Hegel's logicalmetaphysical reasoning with a mechanism of philological validation borrowed from La Scienza Nuova.

With European and Lombard intellectuals re-imagining La Scienza Nuova in increasingly idealist terms, and Cusani and Gatti following Cattaneo in encouraging the full amalgamation of Vichianism and Hegelianism, it was only a matter of time before these two currents of thought merged into a cohesive whole. Central to this operation was Francesco De Sanctis' private school, active between 1839 and 1848. 'i De Sanctis' lectures (1962: 70) on Italian and foreign literature were consistently complemented by the study of French and Neapolitan Enlightenment, as well as German idealism, in an attempt to provide a historicist- 
philosophical understanding of cultural production. During the last two years of his teaching, De Sanctis, who had been, together with Gatti and Cusani, a student of Colecchi's, discussed that which he termed 'historical school' ('scuola storica'), a strand of literary criticism proposing not only an increasingly historicised understanding of culture, but also one stemming from transnational exchanges. Unsurprisingly, Giambattista Vico, to whose ideas De Sanctis had been introduced in 1837 by his friend Enrico Amante, was identified as the founder of this school: 'Vico swapped the life of authors with the life of a people, biography with history' (ibid.). Regarding cultural production as a chronologically-determined reflection of a people's historical existence, Vico had made 'criticism' 'fully historical', introducing the need, for critics, to supplement the contemplation and judgment of works of art with an accurate analysis of the mechanisms able to translate man's experience of history into specific aesthetic forms.

De Sanctis' verdict on Vico, however, was not univocally positive. Surely, he praised him for elaborating a markedly anti-metaphysical speculative method capable of disclosing the workings of a 'Providence able to regulate human events' on the basis of philological proof alone, and of devising 'the laws informing nations' development, as well as an awareness of the various conditions under which the human spirit has appeared' (De Sanctis 1975: III, 928). In contrast, however, he regarded his historicism 'stationary' and, consistent with Cattaneo's interpretation, unable to provide a convincing account of progress (ibid.: III, 1640). Looking at European philosophy, De Sanctis (1926: 23-24) believed, one could identify solutions to Vico's perceived shortcomings: in France, Victor Cousin and Jules Michelet had explored a notion of development understood as the progressive realisation of an absolute principle. Yet it was only in Germany that he regarded an absolute, universal view on history to have been proposed, with idealist philosophers subverting Vichian historicism by attempting to 'cancel the individual out and regard him as posited on Earth for the sole purpose of representing an idea' (ibid.).

These observations did not mean that De Sanctis wholeheartedly embraced Hegel's Geschichtsphilosophie. Consistent with Gatti and Cusani's attempts to draw Hegelianism closer to the anti-metaphysic overtones of Vichian historicism, De Sanctis (1975: III, 756-57) subjected the German philosopher's ideas to close scrutiny, warning against the risks connected with the reliance on a purely ideal notion of history, aided by logical, a priori reasoning alone. 'Pure abstraction', he maintained, 'is not given to man', but can only be 
contemplated 'by descending within the realm of the real' and engaging, à la Vico, with its most tangible realisations. Because 'the Idea without the fact is a utopia; the fact without the Idea relegates civil life to a stationary and merely material existence', De Sanctis (ibid.: III, 7071) urged the crafting of 'an intimate union of philosophy and history, of the idea and the fact' via an amalgamation of Hegelianism and Vichianism that would lead to a composite historicist approach.

In the final lessons of his schools, De Sanctis (ibid.: 756) elucidated this perspective, laying down the coordinates of this new historicism: 'the path we will follow is going to be a dual one, historical or chronological, and logical. By means of a historical method we will proceed from that which is concrete and come to that which is abstract; by means of the logical method, instead, we will proceed in the opposite direction' (see also De Sanctis [1917: 173; 1926: 24] on this topic). Logical reasoning, on the one hand, could disclose the inherent rationality and directionality of history, and render man's experience of it a reflection of absolute and necessary mechanisms, consistent with Hegel's (1820: 14) famous pronouncement that 'that which is rational is real; and that which is real is the rational'. Historical observation, on the other, would disentangle the intelligibility of historical rationality from its metaphysical structure and render it observable within man's actions, intellect and imagination, consistent with Vico's definition of the 'storie di tutte le nazioni' (De Sanctis 1975: III, 789).

The fact that Vico did not directly influence Hegel or other exponents of the German idealist tradition did not prevent nineteenth-century European authors from maintaining that their philosophies of history ought to be seen as complementary. Decoding their relationship is of prime importance in illuminating both Vico's re-discovery in the European context and Hegel's reception among Neapolitan intellectuals. The encounter of Vichianism and Hegelianism largely depended on the fundamentally European dimension of Vico's fortune in the 1800s and was significantly indebted to Michelet, Cuoco and Cattaneo, who projected their own philosophical sensitivities onto La Scienza Nuova. Moreover, as their examples showed, the fact that their reflections on the Neapolitan philosopher's best-known work entailed, more often than not, a revision of its most fundamental aspects is evidence of the ways in which, as a result of transnational exchanges, concepts may take on a life of their own. These considerations intuitively call for methodological adjustments, in order to effectively engage with the polycentric nature of idealism, while remaining sensitive to its 
adaptations to local contexts and intellectual sensitivities. For historians, this is a reminder of the risk of a reified understanding of ideas, stemming from their placement within supra- and transnational contexts, and an exhortation to recognise the extent to which they are themselves the products of those dynamics of exchange, with which transnational history engages (Janz \& Riall 2014). Viewing Neapolitan Hegelianism as thematically connected to German idealism, yet formally distinct from it, and as characteristically informed by local contexts, debates and experiences, yet fully part of a European movement of ideas is a clear means of approaching a degree of equilibrium between transnational and local analyses, an operation of crucial importance in order to obtain a precise understanding and characterisation of Hegelian thought's presence in the southern capital.

These observations ultimately point at the need, for historians, not to regard Hegel's Neapolitan reception as one of mere absorption and passive reception, but one that southern-Italian authors actively shaped. As such, they encourage to articulate a view on Neapolitan Hegelianism placing adequate emphasis on the interpenetration of its local and transnational elements. De Sanctis' amalgamation of Vico and Hegel's philosophies of history revolved around the establishment of a dialectical relationship between the real and the ideal in ways that mirrored Michelet and Cattaneo's efforts to re-describe La Scienza Nuova from the standpoint of Hegelian dialectics. In parallel, De Sanctis' critique of absolute idealism reflected the anti-metaphysical reading of German philosophy popularised in Naples by his mentors Galluppi and Colecchi, and his fellow Hegelians Gatti and Cusani. Seen in the context of his teaching on aesthetics, De Sanctis' (1926: 24; 1975: II, 540-41) composite historicism resulted in a definition of cultural production 'universal in the Idea, since this embraces the entirety of the universe, [...] but social or present in its form'. Philosophically speaking, it was an attempt to mediate between two competing ways of making sense of one's experience of history, by dialectically connecting 'the rational developed within the real' and the 'real elevated to the ideal' (De Sanctis 1917: 173). By the mid-nineteenth century, Vico had become European and Hegel Neapolitan. Their stories are inseparable. 
Bibliography

Archivio delle Civiche Raccolte Storiche di Milano (ACMil), Fondo Carlo Cattaneo

Berlin, I. (1976) Vico and Herder: Two Studies in the History of Ideas. London: Random House

Biscardi, L. \& De Francesco, A. (2002) Vincenzo Cuoco nella Cultura di Due Secoli. Roma: Laterza

Caianiello, S. (2011) “Vico e lo Storicismo Tedesco". Laboratorio dell'ISPF, VIII(1), 71-95

Cattaneo, C. (1839) "Su la Scienza Nuova di Vico". In Cospito, G. (ed.) (2002) La Scienza Nuova dell'Umanità: Scritti Vichiani 1836-1861. Genova: Name, 45-76

Cione, E. (1960) Francesco De Sanctis e i Suoi Tempi. Napoli: Montanino

Colecchi, O. (1843) Sopra Alcune Quistioni le Piú Importanti della Filosofia. Napoli: Manuzio

Cospito, G. (2002) I/ Gran Vico: Presenza, Immagini e Suggestioni Vichiane nei Testi della Cultura Italiana Pre-Risorgimentale, 1799-1839. Genova: Name

Cousin, V. (1828) Cours de l'Histoire de la Philosophie. Paris: Didier

Croce, B. (1922a) La Filosofia di Giambattista Vico. Bari: Laterza

Croce, B. (1922b) La Fortuna del Vico. Bari: Laterza

Crossley, C. (1993) French Historians and Romanticism: Thierry, Guizot, the Saint-Simonians, Quinet, Michelet. London: Routledge

Cuoco, V. (1804) "Giambattista Vico e lo Studio delle Lingue come Documento Storico". In Cortese, N. \& Nicolini, F. (eds.) Scritti Vari. Bari: Laterza, I, 78-81

Cuoco, V. (1806) “La Filosofia di Giambattista Vico". In Cortese, N. \& Nicolini, F. (eds.) Scritti Vari. Bari: Laterza, I, 303-24

Cusani, S. (1838) "Gli Arabi in Italia". II Progresso delle Scienze, Lettere ed Arti, XX, 107-16

Cusani, S. (1842) "Idea d'Una Storia Compendiata della Filosofia". Museo di Letteratura e Filosofia, I(2), $97-120$

De Francesco, A. (1998) “La Fortuna Editoriale del 'Saggio Storico' nel Secolo XIX”. In Cuoco, V. (1998) Saggio Storico sulla Rivoluzione di Napoli. Manduria: Pietro Lacaita Editore, 621-56

De Sanctis, F. (1917) “Lezioni sulla Storia della Critica dal 1839 al 1848”. La Critica, XV, 16-25, 98-107, 170-78, 225-34, 285-89

De Sanctis, F. (1926) "Vico e La Scuola Storica”. In Croce, B. (ed.) Teoria e Storia della Letteratura. Napoli: Morano, I, 61-136

De Sanctis, F. (1962) Memorie e Scritti Giovanili. Bari: Laterza

De Sanctis, F. (1975) Purismo, Illuminismo, Storicismo. Scritti Giovanili e Frammenti di Scuola. Lezioni. Marinari, A. (ed.). Torino: Einaudi

Fisch, M.H. \& Bergin, T.H. (1944) "Introduction". In Id. (eds.) The Autobiography of Giambattista Vico. Ithaca: Cornell University Press, 1-107

Galluppi, P. (1847) Saggio Filosofico sulla Critica della Conoscenza, Ossia Analisi Distinta del Pensiero Umano con un Esame delle Più Importanti Quistioni dell'Ideologia, del Kantismo e della Filosofia Trascendentale. Milano: Borroni e Scotti

Gans, E. (1837) “Vorrede”. In Hegel, G.W.F. (1837) Vorlesungen über die Philosophie der Geschichte. Leipzig: Felix Meiner, v-xx

Gatti, S. (1843) "La Filosofia della Storia". In Scritti Varii di Filosofia e Letteratura, I, 135-65

Gentile, G. (1915) Studi Vichiani. Firenze: Le Monnier 
Haddock, B. \& Sabetti, F. (2014) "Introduction: Vincenzo Cuoco and the Nature of Revolution and Constitutionalism". In Cuoco, V. (2014) Historical Essay on the Neapolitan Revolution of 1799 (Gibbons, D., trans.). Toronto: Toronto University Press, vi-xxxvi

Hamann, J.G. (1777) Lettere: 1770-77. Milano: Vita e Pensiero

Hegel, G.W.F. (1816) Wissenschaft der Logik. Berlin: Suhrkamp

Hegel, G.W.F. (1817) Enzyklopädie der philosophischen Wissenschaften im Grundrisse. Berlin: Suhrkamp

Hegel, G.W.F. (1820) Grundlinien der Philosophie der Rechts. Berlin: Suhrkamp

Herder, J.G. (12.1.1789) "Brief an Caroline Herder vom 12.1.1789". In Meier, A. \& Hollmer, H. (eds.) (1988) Johann Gottfried Herder Italienische Reise. Briefe und Tagebuchaufzeichnungen 178889. München: DTV, 308

Herder, J.G. (1797) Briefe zu Beförderung der Humanität. Leipzig: Hartnoch

Jacobi, F.H. (1811) Von den Göttlichen Dingen und Ihrer Offenbarung. Leipzig: Gerhard Fleischer

Janz, O. \& Riall, L. (2014) “The Italian Risorgimento: Transnational Perspectives. Introduction”. Journal of Modern Italian Studies, XIX(1), 1-4

Kaufmann, W.A. (1965) Hegel: Reinterpretation, Texts and Commentary. Notre Dame, IN: University of Notre Dame Press

Kippur, S.A. (1981) Jules Michelet: A Study of Mind and Sensibility. Albany: State University of New York Press

Lacaita, C.G., Gobbo, R. \& Turiel, A. (2003) La Biblioteca di Carlo Cattaneo. Bellinzona: Casagrande

Losurdo, D. (1997) Dai Fratelli Spaventa a Gramsci. Per una Storia Politico-Sociale della Fortuna di Hegel in Italia. Napoli: La Città del Sole

Macpherson, J. (1768) Die Gedichte Ossians, eines altern celtischen Dichter. Wien: Edlen

Mali, J. (2003) Mythistory: The Making of a Modern Historiography. Chicago: University of Chicago Press

Mali, J. (2012) The Legacy of Vico in Modern Cultural History: From Jules Michelet to Isaiah Berlin. Cambridge: Cambridge University Press

Manzoni, A. (1822) Discorso sopra Alcuni Punti della Storia Longobardica in Italia. Milano: Fratelli Rechiedei

Michelet, J. (1827) Principes de la Philosophie de l'Histoire de Vico. Paris: Renouard

Michelet, J. (1837) Histoire de la France. Paris: Chamerot

Michelet, J. (1839) Histoire Romaine. Paris: Les Belles Lettres

Michelet, J. (1840) Introduction à I'Histoire Universelle. Paris: Flammarion

Michelet, J. (1869) “Unpublished Note”. In Viallaneix, P. (ed.) (1959) La Voie Royale: Essai sur I'Idée de Peuple dans I'Oeuvre de Michelet. Paris: Delagrave

Michelet, J. (1984) Journal. Vialleneix, P. \& Digeon, C. (eds). Paris: Gallimard

Michelet, J. (1994) Correspondance Générale. Paris: Honoré Champion

Momigliano, A. (1966) "Vico's Scienza Nuova: Roman "Bestioni" and Roman "Eroi"”. In Essays in Ancient and Modern Historiography. Chicago: the University of Chicago Press, 253-77

Moravia, S. (1974) "Introduzione". In Id. (ed) Giandomenico Romagnosi. Scritti Filosofici. Milan: Ceschina, 5-52

Oldrini, G. (1969) II Primo Hegelismo Italiano. Firenze: Vallecchi

Oldrini, G. (1973) La Cultura Filosofica Napoletana nell'Ottocento. Bari: Laterza

Origo, G. (2011) Bertrando Spaventa Interprete di Bruno, Vico ed Hegel. Napoli: Bibliosofica

Pepe, G. (1824) “Necrologia. Vincenzo Cuoco”. Antologia, III, 2 
Piovani, P. (1968) "Vico senza Hegel”. In Piovani, P. \& Tessitore, F. (eds.) La Filosofia Nuova di Vico. Napoli: Morano, 553-86

Robertson, G. (2005) The Case for the Enlightenment. Cambridge: Cambridge University Press

Romagnosi, G.D. (1822) “Osservazioni su la Scienza Nuova di Vico”. In Moravia, S. (ed.) Scritti Filosofici, $19-49$

Romagnosi, G.D. (1832) Dell'Indole e dei Fattori dell'Incivilimento con Esempio del suo Risorgimento in Italia. Firenze: Piatti

Romagnosi, G.D. (1832b) “Alcuni Pensieri sopra un'Altra Metafisica Filosofia della Storia”. In Moravia, S. (ed.) Scritti Filosofici, 61-76

Rubini, R. (2016) "The Vichian 'Renaissance' between Giuseppe Ferrari and Michelet". Intellectual History Review, 26(1), 9-15

Salfi, F.S. (1807) Dell'Uso dell'Istoria. Napoli: Agnello Nobile

Spaventa, B. (1862) La Filosofia Italiana nelle sue Relazioni colla Filosofia Europea. Gentile, G. (ed.) (1908). Bari: Laterza

Spaventa, B. (1867) Principii di Filosofia. Napoli: Ghio

Tessitore, F. (1968) "Vico tra Due Storicismi”. II Pensiero, XIII(1), 211-27

Tessitore, F. (1979) "Vico nelle Origini dello Storicismo Tedesco". Bollettino del Centro di Studi Vichiani, IX(1), 5-34

Thom, M. (1995) Republics, Nations and Tribes. London: Verso

Vico, G. (1710) De Antiquissima Italorum Sapientia. Adamo, G. (ed.) (1998). Firenze: Olschki

Vico, G. (1744) La Scienza Nuova. Nicolini, F. (ed.) (1911). Bari: Laterza

\footnotetext{
'This intuition is also visible in Michelet's Introduction à l'Histoire Universelle (1840, 9-28). Moreover, as noted in his Journal, Michelet (1984: I, 384) was well-aware of Vico's cyclical conception of history, which makes its omission in the Principes seem even more deliberate. For a discussion of the philosophical background to Michelet's discussion of Vico, see Kippur (1981: 26-38).

ii In nineteenth-century Naples, any school whose activity took place parallel to, and independently from, that of the institutes directly regulated by the government, would qualify as private. Private schools usually enjoyed unrestricted freedom with regard to the adoption of their teaching methods, the definition of the programmes and the actual length of teaching. Moreover, their students would pay a fee directly to their teacher, but, in some cases, wealthier families would directly fund private instructors, especially when the quality of their public counterparts was particularly low.
} 